\title{
Physical activity of teachers
}

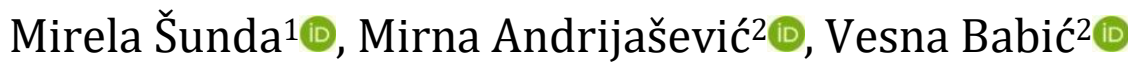 \\ 1 Gymnasium "A.G.Matoš", Đakovo, Đakovo, Croatia. ${ }^{2}$ University of Zagreb, Faculty of Kinesiology, Croatia.
}

\begin{abstract}
The aim of this paper was to determine the level of physical activity of high school teachers and establish whether there were differences in physical activity of female and male teachers during their professional work, travel to and from work, and leisure time taking into consideration their age, gender, and work experience. The study included teachers at a high school in Osijek-Baranja County, Republic of Croatia. The sample included 41 high school teachers aged from 25 to 64. This study used the Croatian version of the Global Physical Activity Questionnaire (GPAQ) as the measuring instrument. The variables of the study were the total physical activity of teachers, physical activity at the workplace, physical activity during travel to and from work, and physical activity during leisure time, sporting and recreational activities. The Man-Whitney U test with the significance level of $\mathrm{p}<$ 0.05 was used to determine the differences between the named arithmetic means. More than half of the total group (76\%) and both males and females were meeting physical activity recommendations of 600 MET (min/week). The results also show that $24 \%$ of teachers engaged in low-intensity physical activities.
\end{abstract}

Keywords. Educators Exercise, leasure time, transport.

\section{Introduction}

In the time of modern technologies dominated by a sedentary lifestyle and stress, a silent killer of the contemporary era, physical activity and its importance should have a significant and indispensable role. Numerous studies testify of an increase of physical inactivity caused by the way of life and a lack of free time. Sindik, et al. (2009) believe that physical activity should be a social priority, since the appearance of modern technology itself has eliminated the fundamental human biological need to be physically active, resulting in a decrease of physical and physiological potential of humans. Physical activity presents an important factor in achieving optimal health (Jurakić \& Andrijašević, 2007). Many studies around the globe testify that physical activity reduces the incidence of various non-infectious chronic diseases and decreases the risk of premature death and depression (Asiamah \& Mensah, 2017). Ratey (2008) in the first edition of his book highlights the importance of physical activity for human brain. Findings of kinesiological research of the last decade point to the alarming fact that motor skills of children and young people have deteriorated and that $35 \%$ of the children aged 8 to 9 are overweight or obese (Musić Milanović et al., 2018). In their research Jurakić et al. (2009) have established that in Croatia there is an unsatisfactory level of physical activity. In 2010, the same authors conducted a research among the working population in their middle years in the Republic of Croatia taking into consideration the characteristics of the workplace and propensity for sporting and recreational activities. Their research also presents general recommendations for physical activity of employees, recommendations for employees who primarily sit, walk or stand during their working hours and recommendations for employees who sit and are under mental pressure and stress at work. Based on the nature of their work, teachers could be grouped in the last category.

The aim of this paper was to determine the level of physical activity of high school teachers and establish whether there are differences in physical activity of female and male teachers during their professional work, commuting and leisure time, taking into consideration their age, gender, and work experience. 


\section{Methods}

\section{Participants}

The study included teachers at a high school in Osijek-Baranja County, Republic of Croatia. Out of the total of 43 teachers in the school, 41 teachers voluntarily decided to participate in the research. There are 13 male and 28 female teachers. Four of them have less than five years of work experience, eight have between five and ten years and nine have between ten and twenty years of work experience, while twenty teachers have been working for more than 20 years. The average age of participants is 45.8 \pm 12.04 years. This study was conducted in accordance with guidelines of the Declaration of Helsinki. All participants signed consent for their participation. The original study was approved by the Ethical Board of the University of Split, Faculty of Kinesiology (EBO: 2181-205-05-02-05-20-004).

\section{Variables}

The variables of the study were the total physical activity of teachers, physical activity at the workplace, physical activity during travel to and from work, and physical activity during leisure time, sporting and recreational activities, gender, age and work experience.

\section{Measurement Instrument}

\section{Global Physical Activity Questionnaire}

This study used the Croatian version of the Global Physical Activity Questionnaire (GPAQ) as the measurement instrument. According to Armstrong and Bull (2006), the World Health Organisation (WHO) developed the GPAQ as a reliable and valid tool for determining physical activity and monitoring its role in the prevention of noncontagious chronic diseases. In recent years many studies have proved the reliability and validity of the GPAQ (Herrman et al., 2013.; Cleland et al.,2014.; Chu et al., 2015.; Wanner et al.,2016.; Lauš and Lauš, 2017.; Rudolf et al., 2020).

The GPAQ encompasses intensity, duration and frequency of physical activity within a week and collects data on physical activity in three areas which include physical activity, i.e. physical activity at the workplace, physical activity during travel to and from work and physical activity during leisure time, sporting and recreational activities. It also measures the time spent sitting. The manner in which the results of GPAQ variables are calculated can be found in the manual and the instructions for GPAQ (GPAQ Analysis Guide, WHO, 2012). The questionnaire was adapted for this research. The intensity of physical activity was presented using the metabolic equivalent (MET), and the level of physical activity by MET (min/week). MET (metabolic equivalent) is usually used for expressing intensity of physical activity as well as for analysing data obtained through the Global Physical Activity Questionnaire. One MET can be observed as the quantity of energy that a person spends while being still and it is equivalent to the consumption of kilocalories per $1 \mathrm{~kg}$ of body weight per hour. It is estimated that the kilocalories consumption of a person who is moderately physically active measures four times and the consumption of the person with a high-intensity physical activity even eight times the consumption of the person sitting still (GPAQ Analysis Guide WHO, 2012).

According to Lauš and Lauš (2017) and WHO (2020), the level of physical activity can be categorised into high, moderate and low level. The high level of physical activity implies physical activity of high or moderate intensity of at least 3000 MET (min/week). The moderate level of physical activity implies the activity of high or moderate intensity of at least $600 \mathrm{MET}$ (min/week), while the low level of physical activity implies physical activity of 600 MET (min/week) at most.

\section{Statistical Analyses}

The descriptive statistical analysis yielded the following parameters: arithmetic mean and standard deviation of the total physical activity of teachers, physical activity at the workplace, physical activity during travel to and from work and physical activity during leisure time, sports and recreation. The normality of variables distribution was tested using the Kolmogorov-Smirnov test. Distributions of all variables significantly differ from the normal distribution at the significance level of $p<0.01$. The Man-Whitney U test with the significance level of $\mathrm{p}<$ 0.05 was used to determine the differences between the named arithmetic means, as illustrated in the text below. The results were processed using the statistical software IBM SPSS 20.

\section{Results}

This research measured physical activity as a sum of MET (min/week) of physical activity during leisure 
time, sporting, and recreational activities, during travel to and from work, and at the workplace. The following analysis revealed the types of activities which contribute to the named difference.

Table 1

Descriptive data based on gender.

\begin{tabular}{|c|c|c|c|c|c|c|c|}
\hline \multirow{2}{*}{ Gender } & & \multirow{2}{*}{$\mathrm{n}$} & \multirow{2}{*}{ M } & \multirow{2}{*}{ SD } & \multicolumn{3}{|c|}{ Percentile } \\
\hline & & & & & 25. & 50. (Me) & 75. \\
\hline \multirow[t]{4}{*}{ Male } & Workplace MET (min/week) & 13 & $1,367.69$ & $1,711.949$ & .00 & 560.00 & $2,880.00$ \\
\hline & Travel to and from work MET (min/week) & 13 & 878.46 & 753.147 & 150.00 & 480.00 & $1,680.00$ \\
\hline & $\begin{array}{l}\text { Leisure time, sporting and recreational } \\
\text { activities MET (min/week) }\end{array}$ & 13 & $2,507.69$ & $2,334.860$ & 720.00 & 960.00 & $4,800.00$ \\
\hline & Total MET (min/week) & 13 & $4,753.85$ & $3,806.901$ & $1,200.00$ & $3,480.00$ & $8,400.00$ \\
\hline \multirow[t]{4}{*}{ Female } & Workplace MET (min/week) & 28 & 350.71 & 664.206 & .00 & .00 & 600.00 \\
\hline & Travel to and from work MET (min/week) & 28 & 813.57 & $1,526.361$ & .00 & 330.00 & 810.00 \\
\hline & $\begin{array}{l}\text { Leisure time, sporting and recreational } \\
\text { activities MET (min/week) }\end{array}$ & 28 & 972.86 & $1,577.351$ & .00 & 270.00 & $1,200.00$ \\
\hline & Total MET (min/week) & 28 & $2,137.14$ & $2,760.804$ & 240.00 & $1,200.00$ & $3,330.00$ \\
\hline
\end{tabular}

$\mathrm{n}$ : Number of participants, M: Mean, SD: Standard deviation, Me: Median

\section{Table 2}

The results of the Mann-Whitney $U$ Test for work experience in relation to gender.

\begin{tabular}{|c|c|c|c|c|c|}
\hline \multicolumn{2}{|l|}{ Gender } & \multirow{2}{*}{$\begin{array}{l}\text { Work experience } \\
<10 \text { years }\end{array}$} & \multirow{2}{*}{$\begin{array}{l}n \\
6\end{array}$} & \multirow{2}{*}{$\begin{array}{c}\text { Mean Rank } \\
9.50\end{array}$} & \multirow{2}{*}{$\frac{U}{-2.207^{*}}$} \\
\hline Male & Workplace MET (min/week) & & & & \\
\hline & & $>10$ years & 7 & 4.86 & \\
\hline & & Total & 13 & & \\
\hline & Travel to and from work MET & $<10$ years & 6 & 9.00 & -1.776 \\
\hline & (min/week) & $>10$ years & 7 & 5.29 & \\
\hline & & Total & 13 & & \\
\hline & Leisure time, sporting and recreational & $<10$ years & 6 & 8.17 & -1.006 \\
\hline & activities MET (min/week) & $>10$ years & 7 & 6.00 & \\
\hline & & Total & 13 & & \\
\hline & Total MET & $<10$ years & 6 & 9.58 & $-2.217^{*}$ \\
\hline & (min/week) & $>10$ years & 7 & 4.79 & \\
\hline & & Total & 13 & & \\
\hline \multirow[t]{12}{*}{ Female } & Workplace MET & $<10$ years & 6 & 12.08 & -.979 \\
\hline & (min/week) & $>10$ years & 22 & 15.16 & \\
\hline & & Total & 28 & & \\
\hline & Travel to and from work MET & $<10$ years & 6 & 15.25 & -.255 \\
\hline & (min/week) & $>10$ years & 22 & 14.30 & \\
\hline & & Total & 28 & & \\
\hline & Leisure time, sporting and recreational & $<10$ years & 6 & 11.75 & -.940 \\
\hline & activities MET (min/week) & $>10$ years & 22 & 15.25 & \\
\hline & & Total & 28 & & \\
\hline & Total MET & $<10$ years & 6 & 12.58 & -.644 \\
\hline & (min/week) & $>10$ years & 22 & 15.02 & \\
\hline & & Total & 28 & & \\
\hline
\end{tabular}




\section{Table 3}

Descriptive data based on work experience.

\begin{tabular}{|c|c|c|c|c|c|c|c|}
\hline \multirow{2}{*}{ Gender } & & \multirow{2}{*}{$\mathrm{n}$} & \multirow{2}{*}{ M } & \multirow{2}{*}{ SD } & \multicolumn{3}{|c|}{ Percentile } \\
\hline & & & & & 25. & 50. (Me) & 75. \\
\hline \multirow{4}{*}{$\begin{array}{l}<10 \\
\text { years }\end{array}$} & Workplace MET (min/week) & 12 & $1,340.00$ & $1,811.840$ & .00 & 360.00 & $3,120.00$ \\
\hline & $\begin{array}{l}\text { Travel to and from work MET } \\
\text { (min/week) }\end{array}$ & 12 & 883.33 & 698.145 & 240.00 & 660.00 & 1.680 .00 \\
\hline & $\begin{array}{l}\text { Leisure time, sporting and recreational } \\
\text { activities MET (min/week) }\end{array}$ & 12 & $2,240.00$ & $2,482.228$ & .00 & $1,440.00$ & $4,260.00$ \\
\hline & Total MET (min/week) & 12 & $4,463.33$ & $4,146.638$ & 420.00 & $3,760.00$ & $8,520.00$ \\
\hline \multirow{4}{*}{$\begin{array}{l}>10 \\
\text { years }\end{array}$} & Workplace MET (min/week) & 29 & 397.24 & 671.049 & .00 & .00 & 640.00 \\
\hline & $\begin{array}{l}\text { Travel to and from work MET } \\
\text { (min/week) }\end{array}$ & 29 & 813.79 & $1,515.935$ & .00 & 300.00 & 900.00 \\
\hline & $\begin{array}{l}\text { Leisure time, sporting and recreational } \\
\text { activities MET (min/week) }\end{array}$ & 29 & $1,136.55$ & $1,640.985$ & 140.00 & 720.00 & $1,200.00$ \\
\hline & Total MET (min/week) & 29 & $2,347.59$ & $2,760,427$ & 690.00 & $1,440,00$ & $3,300,00$ \\
\hline
\end{tabular}

$\mathrm{n}$ : Number of participants, M: Mean, SD: Standard deviation, Me: Median

\section{Table 4}

The results of the Mann-Whitney $U$ Test based on gender taking work experience into consideration.

\begin{tabular}{|c|c|c|c|c|c|}
\hline Gender & & Gender & $n$ & Mean Rank & $U$ \\
\hline \multirow[t]{12}{*}{$<10$ years } & \multirow[t]{3}{*}{ Workplace MET (min/week) } & Male & 6 & 8.92 & $-2.483^{*}$ \\
\hline & & Female & 6 & 4.08 & \\
\hline & & Total & 12 & & \\
\hline & \multirow{3}{*}{$\begin{array}{l}\text { Travel to and from work MET } \\
\text { (min/week) }\end{array}$} & Male & 6 & 8.58 & $-2.041^{*}$ \\
\hline & & Female & 6 & 4.42 & \\
\hline & & Total & 12 & & \\
\hline & \multirow{3}{*}{$\begin{array}{l}\text { Leisure time, sporting and recreational } \\
\text { activities MET (min/week) }\end{array}$} & Male & 6 & 8.67 & $-2.119 *$ \\
\hline & & Female & 6 & 4.33 & \\
\hline & & Total & 12 & & \\
\hline & \multirow{3}{*}{$\begin{array}{l}\text { Total MET } \\
\text { (min/week) }\end{array}$} & Male & 6 & 9.17 & $-2.562^{*}$ \\
\hline & & Female & 6 & 3.83 & \\
\hline & & Total & 12 & & \\
\hline \multirow[t]{12}{*}{$>10$ years } & \multirow{3}{*}{$\begin{array}{l}\text { Workplace MET } \\
\text { (min/week) }\end{array}$} & Male & 7 & 15.29 & -.117 \\
\hline & & Female & 22 & 14.91 & \\
\hline & & Total & 29 & & \\
\hline & \multirow{3}{*}{$\begin{array}{l}\text { Travel to and from work MET } \\
\text { (min/week) }\end{array}$} & Male & 7 & 15.07 & -.026 \\
\hline & & Female & 22 & 14.98 & \\
\hline & & Total & 29 & & \\
\hline & \multirow{3}{*}{$\begin{array}{l}\text { Leisure time, sporting and recreational } \\
\text { activities MET (min/week) }\end{array}$} & Male & 7 & 19.29 & -1.535 \\
\hline & & Female & 22 & 13.64 & \\
\hline & & Total & 29 & & \\
\hline & \multirow{3}{*}{$\begin{array}{l}\text { Total MET } \\
\text { (min/week) }\end{array}$} & Male & 7 & 16.86 & -.663 \\
\hline & & Female & 22 & 14.41 & \\
\hline & & Total & 29 & & \\
\hline
\end{tabular}

$* p<.05$

Table 1 showed that there were differences in physical activity at the workplace, during travel to and from work and during leisure time based on gender, and that male teachers were on average 
significantly more active in all categories than female teachers.

Table 2 showed the relevance of work experience in physical activity of teachers at the workplace, during travel to and from work and during leisure time taking gender into consideration. Younger male teachers differed significantly in MET (min/week) at the workplace and in total MET (min/week) in relation to their older male colleagues.

Table 3 showed that there were differences in physical activity at the workplace, during travel to and from work and during leisure time based on work experience, so that younger teachers were on average more active than their older colleagues.

Table 4 showed the significance of gender in physical activity of teachers at the workplace, during travel to and from work and during leisure time taking work experience into consideration. Younger male teachers statistically significantly differed in MET (min/week) at the workplace, during travel to and from work and during leisure time and in total MET (min/week) in relation to younger female teachers.

\section{Discussion}

The primary aim of this research was to establish the level of physical activity of high school teachers, we also tried to find out difference in the area of: professional teaching work, travel to and from work, leisure time, age, gender and work experience. The sample included 41 high school teachers aged 25 to 64 , with the average age of $45.8 \pm 12.04$ years. The research results show that the participants manifest a high level of physical activity, amounting to 4,753.85 MET (min/week) for male teachers, and 2,137.14 MET (min/week) for female teachers. Physical activity of moderate and high intensity, which benefits health, is recorded for $76 \%$ of teachers while $24 \%$ of teachers engaged in lowintensity physical activities. Taking into consideration the obtained results it is obvious that the participants consider physical activity very important for improving their health and prevention of various diseases. Therefore, the research should be conducted on a larger sample to enable comparison of results and making conclusions. The results of a study conducted on adults in Nepal confirm that about $97 \%$ of men and $98 \%$ of women meet the recommended levels of physical activity but that most participants do not achieve their physical activity in their lesaure time (Pedišić et al., 2019). A study conducted on about 1,700 teachers in Sao Paulo
(Brito et al., 2012) found that teachers generally have low levels of physical activity, which is contrary to what the results of this study show. Brito et al. (2012) showed that is more teachers with a moderate level of physical activity and those teachers who have a high level of physical activity mostly achieve their physical activity in their lesaure and professional time.

The obtained results also indicate that male teachers significantly differ from female teachers in total physical activity as well as physical activity during leisure time, at the workplace, and during travel to and from work, and the difference mainly refers to younger teachers. However, with work experience this difference between male and female teachers reduces. In general, female teachers are less active than male colleagues in all categories. Male teachers perform most physical activities at the workplace and during leisure time, being most active during leisure time while being least active during travel to and from work, presumably because they commute by car. Unlike male teachers, female teachers are equally active in all the three categories, but they are least active in their leisure time. The research results lead to questions such as why female teachers are less active than their male colleagues, whether the reason is a lack of time and/or sporting and recreational habits, whether there is a lack of workout programmes attractive to female teachers, and whether contemporary work conditions and the ways of spending leisure time are in line with today's needs of female teachers. We could even speculate about many other things.

\section{Conclusion}

The surveyed teachers attach great importance to physical activity to improve their health. The results of this study indicate a recommended and sufficient level of physical activity of the surveyed Croatian teachers has been achieved. The sample size does not allow for generalization, so future research should be conducted on a larger sample of Croatian teachers and an equal number of male and female participants. It should also incorporate a comparison of results on physical activity of teachers with data on physical activity of teachers in the other parts of Croatia. At the national level, it would be good to consider improving the working conditions of Croatian teachers, which would raise the quality of life in their leasure time and certainly affect to their working skills, mood and ultimately health. It would be great to develop a strategy of reduction of physical inactivity of teachers and sedentary behavior in the future. 


\section{Funding}

The authors received no financial support for the research.

\section{Conflict of Interests}

Authors have declared that no competing interest exists.

\section{References}

Armstrong, T., \& Bull, F. (2006). Development of the world health organization Global Physical Activity Questionnaire (GPAQ). Journal of Public Health, 14(2), 66-70.

Asiamah, N. \& Mensah, H. K. (2017). The Association between Work-Related Physical Activity and Depression. Journal of Physical Activity Research, 2(1), 1-6.

Brito, W. F., Santos, C. L., Marcolongo, A., Campos, M. D., Bocalini, D. S., Antonio, E. L., Silva Junior, J. A., Tucci, P. J., \& Serra, A. J. (2012). Physical activity levels in public school teachers. Revista de saude publica, 46(1), 104109.

Bull, F.C., Maslin, T.S., \& Armstrong, T. (2009). Global physical activity questionnaire (GPAQ): nine country reliability and validity study. J Phys Act Health, 6, 790804.

Chu, A.H.Y., Ng, S.H.X., Koh, D., \& Müller-Riemenschneider, F. (2015). Reliability and validity of the self- and interviewer-administered versions of the global physical activity questionnaire (GPAQ). PLoS One, 10(9), e0136944.

Cleland, C.L., Hunter, R.F., Kee, F., Cupples, M.E., Sallis, J.F., \& Tully, M.A. (2014). Validity of the global physical activity questionnaire (GPAQ) in assessing levels and change in moderate-vigorous physical activity and sedentary behaviour. BMC Public Health, 14, 1255.

Herrmann, S.D., Heumann, K.J., Der Ananian, C.A., \& Ainsworth, B.E. (2013). Validity and reliability of the global physical activity questionnaire (GPAQ). Meas Phys Educ Exerc Sci, 17, 221-235.

Jurakić, D., Pedišić, Ž., \& Andrijašević, M. (2009). Physical activity of Croatian population: Cross-sectional study using International Physical Activity Questionnaire. Croatian Medical Journal, 50(2), 163-168.

Jurakić, D., Pedišić, Ž., \& Andrijašević, M. (2010). Osnove strategije za unapređenje tjelesne aktivnosti i zdravlja zaposlenika srednje dobi s obzirom na obilježja radnog mjesta i skolnosti ka sportsko-rekreacijskim aktivnostima. Sociologija i prostor, 48, 186(1), 113131.
Lauš, F., \& Lauš, D. (2017). Tjelesna aktivnost policijskih službenica. Policija i sigurnost, (3), 187-197.

Musić Milanović, S., Lang Morović, M. \& Markelić, M. (2018). Europska inicijativa praćenja debljine u djece, Hrvatska 2015./2016. (CroCOSI). Hrvatski zavod za javno zdravstvo, Downloaded from: https://www.hzjz.hr/wpcontent/uploads/2018/05/CroCOSI-izvjesce-HRweb.pdf, Accessed 10 April 2020.

Pedisic, Z., Shrestha, N., Loprinzi, P.D., Mehata, S., \& Mishra, S.R. (2019). Prevalence, patterns, and correlates of physical activity in Nepal: findings from a nationally representative study using the Global Physical Activity Questionnaire (GPAQ). BMC Public Health, 19, 864.

Ratey, J.J., \& Hagerman, E. (2008). Spark: The revolutionary new science of exercise and the brain. New York: Little Brown.

Rudolf, K., Lammer, F., Stassen, G., Froböse, I., \& Schaller, A. (2020). Show cards of the Global Physical Activity Questionnaire (GPAQ) - do they impact validity? A crossover study. BMC Public Health, 20, 223.

Sindik, J., Andrijašević, M., \& Ćurković, S. (2009). Rrelation of student attitude toward leisure time activities and their preferences toward sport recreation activities. Acta Kinesiologica, 3(1), 54-58.

Shah, H., Dhami, H., \& Shah, T. (2016). Assessment of physical activity level in female students of residential college using global physical activity questionnaire: A cross sectional analysis. International Journal of Current Research and Review, 8(13), 24.

Tomašić, S., Horvat, G., \& Leutar, Z. (2016). Stress intensity in primary school teachers. Socijalne teme, 1(3), 49-65.

Wanner, M., Hartmann, C., Pestoni, G., Martin, B.W., Siegrist, M., \& Martin-Diener, E. (2017). Validation of the global physical activity questionnaire for selfadministration in a European context. BMJ Open Sport Exerc Med, 3: e000206.

World Health Organization (2012). Global Physical Activity Questionnaire (GPAQ) analysis guide. Downloaded from:

http://www.who.int/chp/steps/resources/GPAQ_Ana lysis_Guide.pdf, Accessed 30 October 2017.

World Health Organization (2020). Physical Activity. Downloaded from: https://www.who.int/newsroom/fact-sheets/detail/physical-activity, Accessed 9 April 2020.

U. S. Department of Health and Human Services (2019). Physical activity builds a healthy and strong America. Downloaded from: https://www.cdc.gov/ physicalactivity/about-physical-activity/pdfs/healthystrong-america-201902_508.pdf, accessed 9 April 2020. 